\title{
Evaluation of the Nutritional, Phytochemical and Antioxidant Properties of the Peels of Some Selected Mango Varieties
}

\author{
John O. Onuh ${ }^{1, *}$, Gideon Momoh ${ }^{1}$, Simeon Egwujeh ${ }^{1}$, Felicia Onuh ${ }^{2}$ \\ ${ }^{1}$ Department of Food, Nutrition \& Home Sciences, Kogi State University, Anyigba, Kogi State, Nigeria \\ ${ }^{2}$ Department of Food Science and Technology, University of Nigeria, Nsukka, Nigeria \\ *Corresponding author: onuh.jo@ksu.edu.ng
}

\begin{abstract}
Peels of 3 varieties of mango (Julie, Peter and Paparanda) were evaluated to determine the effects of varietal differences on the nutritional, phytochemical and antioxidant properties of peels of the selected varieties. Peels from moderately ripe mango fruits were processed into mango peel flour and analyzed for their nutritional, phytochemical and antioxidant properties. The results showed that mango varieties significantly differ from each other in their nutritional compositions. Peter variety had significantly highest values in both vitamins A ( $\beta$-carotene) and $\mathrm{C}$ while Paparanda variety had significantly lowest values. Beta-carotene content of mango peels significantly ranged from 9.14 to $11.98 \mu \mathrm{g} / \mathrm{g}$ while the vitamin C content ranged from $21.66 \mu \mathrm{g} / \mathrm{g}$ to $51.54 \mu \mathrm{g} / \mathrm{g}$. There is also great variation in the phytochemical compositions of the peels of the different varieties suggesting that they might have bioactive and functional properties. DPPH scavenging activities of the mango peels are significantly different from each and are also concentration dependent. They correlated with the vitamin C and polyphenolic content. Mango peels could therefore offer low-cost dietary supplements for low income groups as well as serve as potential source of functional ingredient in processed foods for the control, management and treatment of oxidative stress induced health disorders.
\end{abstract}

Keywords: mango peels, varieties, nutritional, phytochemicals, antioxidant, bioactive

Cite This Article: John O. Onuh, Gideon Momoh, Simeon Egwujeh, and Felicia Onuh, "Evaluation of the Nutritional, Phytochemical and Antioxidant Properties of the Peels of Some Selected Mango Varieties." American Journal of Food Science and Technology, vol. 5, no. 5 (2017): 176-181. doi: 10.12691/ajfst-5-5-2.

\section{Introduction}

There is an increasing attention by scientists and researchers for the development of novel dietary approaches to combat various physiological threats in the vulnerable segments due to the growing world nutritional problems [1]. Nutritional diversity is the vital component of food system focusing on balanced nutrition for holistic outcomes [2,3]. Fruits and vegetables based nutraceuticals and functional foods have the potentials to alleviate the dietary challenges of target populations owing to their natural therapeutic capacities against terminal degenerative diseases [4,5]. Consequently, attention is being focused on food based bioactive and functional ingredients as one of the primary vehicles for attainment of this goal for consumers from diverse socio-economic communities owing to the fact that they exert a positive impact on health and longevity $[5,6]$. However, fruits and vegetables processing industries generates million tons of wastes and food processing by-products annually that are creating huge disposal problems and aggravating environmental pollution [7]. Thus, the disposal of these wastes and by-products in an efficient, proper and inexpensive manner is one of the basic requirements for a friendly ecosystem. Interestingly, industrial residues especially from fruits and vegetables peels are often considered a concentrated source of phyto-nutrients and have subsequently acquired the attention of scientists, researchers and processors $[6,8,9]$.

Phytochemicals have been defined as "compounds that act as free radical scavengers to help eliminate highly charged oxygen molecules that are by-products of metabolized oxygen molecules" [1,10]. They are believed to offer various health benefits [6,11]. Natural or food-derived antioxidants are gaining popularity owing to their cheap cost, safe status and effectiveness in the physiological system [6,12]. These compounds act as free radical scavengers, metal chelators, free radical chain reaction and oxidative enzymes inhibitors and antioxidant enzyme cofactors [5,12]. During normal metabolic processes, free radicals are generated in the body that induces cellular damage in several ways, with the most deleterious of these effects being DNA damage [13,14]. Besides, oxidized low density lipoprotein (LDL), a product of free radical reaction is one the causative agents for the development of coronary diseases [5]. The diverse phenolic compounds of plant origin exhibit differential antioxidative activity against reactive oxygen species by scavenging hydroxyl and peroxyl radicals and singlet oxygen quenching thereby inhibiting lipid peroxidation [5]. 
Mango (Mangifera indica) is a popular fruit worldwide due to its sweet taste and high nutrient ccontent and is widely grown in tropical regions of the globe $[10,15,16]$. Currently, it is considered the $5^{\text {th }}$ largest fruit in production output throughout the world. Mango is mainly composed of the pulp, kernel and peel (33 - 70, 7 - 24 and 15 - 20\% respectively) of the total fruit weight. Nutritionally, mango peel contains moisture, protein, ash, fibre and carbohydrates as 68.50, 2.05, 2.62, 5.40 and $26.5 \%$, respectively and $453.92 \mathrm{~kJ} / 100 \mathrm{~g}$ of energy [9,17]. Its peel is a promising source of phytonutrients such as polyphenols, carotenoids and vitamin E and C [7,11]. Interestingly, polyphemol contents of mango peels are reportedly higher than in the pulp and are affected by several factors including climatic conditions, agronomic practices and varietal differences [7,9]. However, the effects of varietal differences on the phytochemical contents of the peels have not be properly investigated. Also, mango peels which constitutes a huge waste disposal problem can be harnessed by processing into mango peel flour that can be used as an ingredient in the development of health promoting functional foods and nutraceuticals [11]. The objective of this study therefore is to evaluate the effects of varietal differences on the phytochemical composition of the peels of some selected mango varieties.

\section{Materials and Methods}

\subsection{Materials}

Three different varieties of mangoes (Paparanda, Julie and Peter) were purchased from a local market in Makurdi, Benue state. They were thereafter transported to the Food Science and Technology Laboratory for processing into peel flour and packaged adequately under refrigerated condition until required for analysis. All analytical grade reagents were obtained from the Food Chemistry Laboratory of the Kogi State University, Anyigba - Nigeria.

\subsection{Sample Preparation}

The selected varieties were individually processed into mango peel flour according to the method of Badifu et al [17] with slight modifications. Moderately ripe mango fruits were sorted, washed under clean running tap water. The epicarp (peel) was carefully separated from the mesocarp with the aid of a sharp kitchen knife, sliced thinly and dried in a Genlab (Widnes, England) hot air oven dryer at $60^{\circ} \mathrm{C}$ to a moisture content of $8-10 \%$. The dried mango peel slices were subsequently milled with a disc attrition mill and sieved into a fine flour using a muslin cloth. The dried mango peel flour samples were thereafter packaged in airtight polyethylene packages and stored in the refrigerator until required for analysis.

\subsection{Sample Analyses}

\subsubsection{Proximate Analysis of Mango Peel Flours}

The moisture content of the mango peel flour samples was determined by drying sample in a forced Genlab
(Widnes, England) air oven at $105^{\circ} \mathrm{C}$ according to the guidelines of AOAC [18] methods. Crude protein ( $\mathrm{N} \mathrm{x}$ 6.25) was estimated through Kjeltec apparatus according to the protocol of AOAC [18] methods. Crude fat content of the mango peel flour samples was estimated using hexane as solvent in soxtec system as described in AACC [19]. Total ash content was estimated by direct incineration of dried sample in a muffle furnace at $550^{\circ} \mathrm{C}$ after charring till greyish white residue by according to method of AACC [19]. Crude fibre content was determined by digesting the fat free samples in $1.25 \%$ $\mathrm{H}_{2} \mathrm{SO}_{4}$ followed by $1.25 \% \mathrm{NaOH}$ using Labconco fibretech according to AACC [19] methods. Total carbohydrate was calculated by difference (total carbohydrate $=100$ - (moisture + crude protein + crude fat + crude fibre + ash) according to Ihekoronye and Ngoddy [20].

\subsubsection{Mineral Elements Determinations}

Ash from mango peel flour samples was analyzed for mineral elements (calcium, magnesium and iron) determination using an atomic absorption spectrophotometer (AAS) according to the method of AOAC [18].

\subsubsection{Determination of Vitamins}

Vitamin A (beta carotene) contents of mango peel flour samples were determined on a $5 \mathrm{~g}$ sample according to the method of Reddy and Sistrunk [21] while vitamin C (ascorbic acid) contents were determined by the according to the method of Pearson [22] on 5g sample.

\subsubsection{Quantitative Determination of Phytochemicals}

The alkaloid content of mango peel flour samples was determined according to the modified method of Harbone [23] on a $0.5 \mathrm{~g}$ sample dissolved in $96 \%$ ethanol: $20 \%$ $\mathrm{H}_{2} \mathrm{SO}_{4}$. The aluminium chloride colorimetric method was used for the determination of the flavonoid content of mango peel samples according to the procedure reported by Woisky and Salatino [24]. The method of Burns et al. [25] was adopted for the determination of the saponin content of mango peel samples. Tannin content of mango peel samples was determined using the AOAC [18] method on a $0.2 \mathrm{~g}$ sample. The concentration of phenols in the mango peel was determined using the Folin-Ciocalteu colorimetric method as described by Grussu et al [26] with $1000 \mu \mathrm{M}$ solution of catechin as the standard. An aliquot of standard, blank, or the extract (up to $100 \mu \mathrm{l}$ ) will be added to $1000 \mu \mathrm{l}$ of the Folin-Ciocalteu reagent (Sigma Chemical Company, St. Louis, MO), which has been diluted previously 1:9 with water. The solution will be allowed to stand at $20-25^{\circ} \mathrm{C}$ for $20 \mathrm{~min}$ before colorimetric measurement at $750 \mathrm{~nm}$.

\subsubsection{Determination of in Vitro Antioxidant Properties}

\subsubsection{Determination of DPPH Scavenging Activity}

The in vitro antioxidant activities of mango peels samples were measured on the basis of the scavenging activity against 1,1 - diphenyl 2 - picrylhydrazyl (DPPH) radical according to the method described by BrandWilliams et al [27] with slight modifications. One $\mathrm{ml}$ of $0.1 \mathrm{mM}$ DPPH solution in methanol was mixed with $1 \mathrm{ml}$ 
of mango peel flour sample extract solution of varying concentrations (1000, 500, 250, 125, 62.5 and 31.25 $\mu \mathrm{g} / \mathrm{ml})$. Corresponding blank was prepared and L-ascorbic acid $(1-100 \mu \mathrm{g} / \mathrm{ml})$ was used as reference standard. The reaction was carried out in triplicates and decreases in absorbance were measured at $517 \mathrm{~nm}$ after 30 minutes in the dark using UV - VIS spectrophotometer. The inhibition percentages (\%) was calculated according to the given formula;

$$
\text { Inhibition }(\%)=[(\mathrm{AB}-\mathrm{AA}) / \mathrm{AB}] \times 100
$$

where

$\mathrm{AB}=$ Absorbance of blank sample $(\mathrm{t}=0 \mathrm{~min})$

$\mathrm{AA}=$ Absorbance of tested extract solution $(\mathrm{t}=15 \mathrm{~min})$

\subsubsection{Statistical Analysis}

Results of all determinations were expressed as means of triplicate values. Data were subjected to one-way Analysis of Variance (ANOVA) and significant differences detected using Tukey's test. An IBM SPSS Statistical package (version 20.0) was used for all statistical analyses.

\section{Results and Discussions}

Dietary phytonutrients are known to provide protection against various metabolic conditions and as a consequence, improve the overall health status of individuals. Mango peels being a potential source of bioactive compounds, has the ability to ameliorate various lifestyle related disorders. In this present study, peels from different mango varieties were analyzed for nutritional, phytochemical and antioxidant properties.

\subsection{Proximate Composition}

The proximate compositions of mango peels of the three varieties (Paparanda, Julie and Peter) are shown in Table 1 . The moisture content ranged from 8.13 to $9.30 \%$ with the peels of the Julie variety having significantly lowest values compared to peels from the Peter variety with the highest moisture content value. The peels from the Julie and Paparanda varieties are however not significantly different from each other in their moisture contents. The total ash content in mango peels significantly ranged from $1.38 \%$ (Paparanda) to $1.57 \%$ (Peter) while the peels of Julie variety has ash content of 1.50. The crude fiber content ranged from 13.79 to $15.45 \%$ with Julie significantly having the lowest value while Peter has the highest value. The peels of Peter and Paparanda varieties are also not significantly different from each other in their crude fiber contents. The samples are significantly different from each other in their crude fat contents, ranging from $5.85 \%$ for Julie to $6.52 \%$ for Peter varieties respectively. The mango peels are significantly different from each other in their crude protein content with values of $1.93 \%, 2.14 \%$ and $2.48 \%$ for Paparanda, Julie and Peter varieties respectively. However, for the carbohydrate content in the mango peels, the values ranged from 64.83 to $68.69 \%$ with Peter having significantly lowest value while Julie had significantly the highest value. The results of the present investigation are in accordance with the previous findings of Ajila et al. [9] who reported moisture, protein, fat, fiber and ash contents in the range of 66 - 75, 1.76 - 2.05, 2.16 - 2.66, $3.28-7.40$ and 1.16 - 3.0\%, respectively. Ashoush et al. [28] also estimated the ash, fat, protein and crude fiber contents of mango peel powder to be 3.88, 3.6 and 9.33\%, respectively. The variations in the proximate composition of different mango peel samples may likely be due to varietal differences, climatic conditions, topographic locations and agronomic practices [16]. The high nutrient content of mango peels may support the use of mango peel flour for food enrichment in other to increase the nutritional quality of food products, especially cereal foods [11].

\subsection{Mineral Composition}

The mineral composition of mango peels from the three varieties are shown in Table 2. Ca content of the mango peel samples are significantly different from each other with values ranging from 60.40 (Paparanda) to $67.47 \mathrm{mg} / 100 \mathrm{~g}$ (Peter). The samples are also significantly different from each other in their $\mathrm{Mg}$ contents with Paparanda having the significantly lowest value (94.83mg/100g) while Peter had the significantly highest value (112.20 mg/100g). The Fe content also followed similar trends as reported for $\mathrm{Ca}$ and $\mathrm{Mg}$, and significantly ranged from 10.48 to $13.50 \mathrm{mg} / 100 \mathrm{~g}$ with Paparanda having the lowest value while Peter had the highest value. Similarly, Burns et al [25] also observed variations in calcium, magnesium and iron contents in mango peels ranging from 153 - 167, 31 - 41 and 194 - $217 \mathrm{mg} / 100 \mathrm{~g}$, respectively. The compositional variations among different peel samples regarding proximate and mineral assays are possibly due to varietal differences, soil type, environmental and climatic conditions and fruit maturity stage as had earlier been observed by Palafox-Carlos et al [16].

Table 1. Proximate composition of the peels of different mango varieties

\begin{tabular}{cccccc}
\hline Samples & Moisture & Ash & Crude fibre & Fat & Protein \\
\hline Paparanda & $8.45 \pm 0.28^{\mathrm{a}}$ & $1.38 \pm 0.03^{\mathrm{a}}$ & $15.40 \pm 0.39^{\mathrm{b}}$ & $6.18 \pm 0.03^{\mathrm{b}}$ & $1.93 \pm 0.05^{\mathrm{a}}$ \\
Julie & $8.13 \pm 0.08^{\mathrm{a}}$ & $1.50 \pm 0.00^{\mathrm{b}}$ & $13.79 \pm 0.16^{\mathrm{a}}$ & $5.85 \pm 0.05^{\mathrm{a}}$ & $2.14 \pm 0.08^{\mathrm{b}}$ \\
Peter & $9.30 \pm 0.20^{\mathrm{b}}$ & $1.57 \pm 0.03^{\mathrm{c}}$ & $15.45 \pm 0.08^{\mathrm{b}}$ & $6.52 \pm 0.10^{\mathrm{c}}$ & $2.48 \pm 0.09^{\mathrm{c}}$ \\
\hline
\end{tabular}

All data are means \pm SD of three replicates. Mean values followed by different letters in the same column differs significantly ( $\leq \leq 0.05$ ). 
Table 2. Mineral composition of the peels different mango varieties (mg/100g)

\begin{tabular}{cccc}
\hline Samples & Ca & Mg & Fe \\
\hline Paparanda & $60.40 \pm 0.17^{\mathrm{a}}$ & $94.83 \pm 0.21^{\mathrm{a}}$ & $10.48 \pm 0.30^{\mathrm{a}}$ \\
Julie & $63.52 \pm 0.43^{\mathrm{b}}$ & $109.15 \pm 0.13^{\mathrm{b}}$ & $12.70 \pm 0.26^{\mathrm{b}}$ \\
Peter & $67.47 \pm 0.31^{\mathrm{c}}$ & $112.20 \pm 0.26^{\mathrm{c}}$ & $13.50 \pm 0.20^{\mathrm{c}}$ \\
\hline
\end{tabular}

All data are the means \pm SD of three replicates. Mean values followed by different letters in the same column differs significantly $(\mathrm{p} \leq 0.05)$.

\subsection{Vitamin A and C Contents of Mango Peels}

The vitamin composition of Paparanda, julie and Peter mango peels are shown in Table 3 . The vitamins contents of the mango peel samples are significantly different from each other with Peter variety having significantly highest values while Paparanda variety had significantly lowest values in both vitamins $A$ ( $\beta$-carotene) and $C$. The $\beta$-carotene content of mango peels ranged from 9.14 to $11.98 \mu \mathrm{g} / \mathrm{g}$. Burns et al. [25] reported on the presence of $\alpha$-tocopherol in mango pulp. However, $\beta$-carotene, xanthophyll esters and xanthophylls have also been reported to be the principal carotenoids in mango peels [11]. The vitamin C content ranged from $21.66 \mu \mathrm{g} / \mathrm{g}$ (Paparanda) to $51.54 \mu \mathrm{g} / \mathrm{g}$ (Peter). Vitamin C is known to act as a natural antioxidant substance as well as assist in wound healing.

Table 3. Vitamin A and C composition of the peels of different mango varieties

\begin{tabular}{ccc}
\hline Sample & Vitamin A & Vitamin C \\
\hline Paparanda & $9.14 \pm 0.04^{\mathrm{a}}$ & $21.66 \pm 0.06^{\mathrm{a}}$ \\
Julie & $11.32 \pm 0.04^{\mathrm{b}}$ & $40.17 \pm 0.04^{\mathrm{b}}$ \\
Peter & $11.98 \pm 0.31^{\mathrm{c}}$ & $51.54 \pm 0.07^{\mathrm{c}}$ \\
\hline
\end{tabular}

All data are the means \pm SD of three replicates. Mean values followed by different letters in the same column differ significantly $(\mathrm{P} \leq 0.05)$.

\subsection{Phytochemical Composition of the Peels of Different Mango Varieties}

Table 4 shows the results of phytochemical analyses of the peels of different mango varieties. The flavonoid content of mango peels significantly ranged from 29.04 to $37.18 \mathrm{~g} / 100 \mathrm{~g}$, respectively with Paparanda variety having significantly highest value followed by Peter and then Julie. Similar trends were observed for tannins and alkaloids contents. The tannin content ranged from 15.91 to $24.27 \mathrm{~g} / 100 \mathrm{~g}$ while the alkaloids contents ranged from 0.25 to $0.29 \mathrm{~g} / 100 \mathrm{~g}$, respectively. However, the saponin content ranged from 2.64 to 3.94 g/100g with Peter having the significantly lowest value compared to Julie and Paparanda. The results of the total phenolic contents for mango peel varieties showed that the highest total phenolic content was observed in Paparanda (436.44 $\mathrm{mg} / 100 \mathrm{~g}$ ) followed by Peter (243.93 mg/100g) and the lowest total phenolic content was found in Julie (237.13 $\mathrm{mg} / 100 \mathrm{~g}$ ) mango peels. The values are also significantly different from each other. These values are comparable with the findings of Kim et al. [10] and Kim et al. [15] who examined the antioxidant capacity of ripened and unripened peels of different mango cultivars through total phenolic estimation. They observed higher total phenolic content 90 - $110 \mathrm{mg} / \mathrm{g}$ in ripened peels as compared to raw $55-85 \mathrm{mg} / \mathrm{g}$ on dry basis. They concluded that the total phenolic contents were affected by maturity stage, cultivar type and agronomic practices. The high bioactive and phytochemical content of mango peels may promote their use as antioxidant, antiproliferative, antimutagenic and other health promoting properties $[9,11]$.

\subsection{DPPH Radical Scavenging Activity of Mango Peels}

Antioxidants have been reported to play very crucial role in human health and nutrition owing to their protective effects against reactive oxygen species (ROS) $[13,14]$. The 1,1 diphenyl-2-picryl hydrazyl radical scavenging activities (DPPH) is one of the most widely used methods for screening the antioxidant activities of mango peel extracts. According to Onuh et al. [12], DPPH is a stable free radical with a maximum absorbance at 517 $\mathrm{nm}$ in methanol and as a consequence, it can be widely used to test the reducing properties of many compounds (including natural substances) as well their ability to donate hydrogen by acting as antioxidants. Table 5 shows the antioxidant activities of the methanolic extract of the mango peels assessed using the DPPH radical scavenging. $1000-500 \mu \mathrm{g} / \mathrm{ml}$ of the methanolic extract produced moderate to high DPPH scavenging activities in all the three experimental peels. At $1000 \mu \mathrm{g} / \mathrm{ml}$, the highest DPPH scavenging activities was observed in Peter (97.99\%), followed by Julie (97.77\%) and then Paparanda (95.05\%). At $500 \mu \mathrm{g} / \mathrm{ml}$, the highest DPPH scavenging activities was found in Julie with (97.92\%) followed by Paparanda (9.21\%) and then Peter with (95.91\%). At 250 $\mu \mathrm{g} / \mathrm{ml}$, the highest DPPH scavenging activities was Peter with (98.07\%) followed by Julie with (96.54\%) scavenging activities then Paparanda with (94.16\%). At $125 \mu \mathrm{g} / \mathrm{ml}$, Peter has the highest scavenging activities of (95.83\%) followed by Julie with (94.34\%) and Paparanda with (89.73\%). At $62.5 \mu \mathrm{g} / \mathrm{ml}$, Peter has the highest DPPH scavenging activities with the maximum value of (92.86\%), then Paparanda with (87.05\%) followed by Julie with (79.09\%). At $31.25 \mu \mathrm{g} / \mathrm{ml}$, Peter was more active in the scavenging activities with (92.04\%) followed by Paparanda with (76.11\%) then Julie with (50.56\%) scavenging activities respectively.

Table 4. Phytochemical compositions of the peels of different mango varieties

\begin{tabular}{ccccc}
\hline Samples & Flavonoids & Tannin & Alkaloids & Saponins \\
\hline Paparanda & $37.18 \pm 0.17^{\mathrm{c}}$ & $24.27 \pm 0.05^{\mathrm{c}}$ & $0.27 \pm 0.01^{\mathrm{b}}$ & $3.94 \pm 0.14^{\mathrm{c}}$ \\
Julie & $29.04 \pm 0.28^{\mathrm{a}}$ & $15.91 \pm 0.04^{\mathrm{a}}$ & $0.25 \pm 0.01^{\mathrm{a}}$ & $3.04 \pm 0.00^{\mathrm{b}}$ \\
Peter & $33.18 \pm 0.17^{\mathrm{b}}$ & $19.31 \pm 3.80^{\mathrm{b}}$ & $0.29 \pm 0.01^{\mathrm{b}}$ & $2.64 \pm 0.00^{\mathrm{a}}$ \\
\hline
\end{tabular}

All data are the means \pm SD of three replicates. Mean values followed by different letters in the same column differ significantly (P $\leq 0.05)$. 
Table 5. DPPH radical scavenging property of mango peels

\begin{tabular}{ccccc}
\hline Concentration $(\boldsymbol{\mu g} / \mathbf{m l})$ & \multicolumn{2}{c}{ \% scavenging activity } & Peter & Ascorbic standard \\
\hline $\mathbf{1 0 0 0}$ & Paparanda & Julie & $97.99 \pm 0.22^{\mathrm{d}}$ & $93.80 \pm 0.70^{\mathrm{a}}$ \\
$\mathbf{5 0 0}$ & $95.05 \pm 0.39^{\mathrm{e}}$ & $97.77 \pm 0.23^{\mathrm{e}}$ & $92.10 \pm 0.78^{\mathrm{a}}$ \\
$\mathbf{2 5 0}$ & $96.21 \pm 0.56^{\mathrm{f}}$ & $97.92 \pm 0.17^{\mathrm{e}}$ & $91.59 \pm 0.34^{\mathrm{a}}$ & $91.10 \pm 0.70^{\mathrm{b}}$ \\
$\mathbf{1 2 5}$ & $94.16 \pm 0.28^{\mathrm{d}}$ & $96.54 \pm 0.22^{\mathrm{d}}$ & $98.07 \pm 0.28^{\mathrm{d}}$ & $89.90 \pm 0.75^{\mathrm{c}}$ \\
$\mathbf{6 2 . 5}$ & $89.73 \pm 0.29^{\mathrm{c}}$ & $94.34 \pm 0.23^{\mathrm{c}}$ & $95.83 \pm 0.23^{\mathrm{c}}$ & $87.57 \pm 0.72^{\mathrm{c}}$ \\
$\mathbf{3 1 . 2 5}$ & $87.05 \pm 0.29^{\mathrm{b}}$ & $79.09 \pm 0.23^{\mathrm{b}}$ & $92.86 \pm 0.23^{\mathrm{b}}$ & $84.36 \pm 0.47^{\mathrm{c}}$ \\
\hline
\end{tabular}

All data are the means \pm SD of three replicates. Mean values followed by different letters in the same column differ significantly (P $\leq 0.05)$.

Generally, the antioxidant properties of the mango peels (Paparanda, Julie and Peter mangoes) are significantly different and are found to be concentration dependent. Based on the results obtained, the methanolic extract which is a polar solvent extract were more effective in antioxidant extraction compared to the non-polar hexane extract in DPPH. These results are in agreement with the findings of Ayala-Zavala et al [29]. They evaluated the effect of different concentrations on DPPH activity of mango peel. They were of the view that polyphenol concentration has linear association with DPPH activity and observed $67.97 \%$ free radical inhibition at highest polyphenolic concentration (322 mg/ml). Previously, Ribeiro et al [30] observed that mango peel has higher free radical scavenging activity $53.3 \%$ than that of seed $24.2 \%$. It is also interesting to note that the DPPH result correlates with the total phenolic content, suggesting that the antioxidant effect may be directly related to the total phenol content [16].

\section{Conclusions}

Mango peels are rich in several nutritionally, bioactive and economically important components. There is a great variation in these components among the various mango varieties evaluated. The peels are therefore, capable of offering low-cost nutritional dietary supplement for lower income masses. Mango peels could also be used as a potential source of functional food ingredients in processed food products such as bakery products, breakfast cereals, pasta products, bars and beverages. This could also help in the control, management and treatment of oxidative stress induced health disorders. Additionally, utilization of mango peels not only promotes value addition but also helps to reduce waste generation, environmental pollution and reduced cost in waste disposal.

\section{Acknowledgements}

The authors are grateful to the management of Kogi State University, Anyigba, Nigeria, for the research environment necessary to carry out this research work. We also grateful to Dr. T. F. Emmanuel and Mr. Olusegun Olupinyo for their technical assistance in the conduct of this research study.

\section{Funding}

This research did not receive any specific grant from funding agencies in the public, commercial or not-forprofit sectors.

\section{Highlights}

- Mango peels has high contents of nutritional and bioactive components.

- These components vary depending on the variety of mango evaluated.

- Mango peels could therefore be used as a potential source of functional food ingredients in processed food products.

- They could also be used in the control, management and treatment of oxidative stress induced health disorders.

- Additionally, utilization of mango peels also helps to reduce waste generation, environmental pollution and reduced cost in waste disposal.

\section{References}

[1] Tiwari, B. K., Brunton, N. P., and Brennan, C. S. (2013). Handbook of Plant Food Phytochemicals: source, stability and extraction. John Wiley \& Sons Ltd, West Sussex, UK, pp. 1-50.

[2] Anuonye, J.C., Onuh, J.O., Chidi, E and Shem, E. (2009). Nutrient and antinutrient composition of extruded acha/soybean blends. Journal of Food Processing and Preservation. 34: 680-691.

[3] Onuh, J. O and Akpa. T. E. (2007). Chemical, Physical and sensory properties of "fura" fortified with mango pulp flour. Savanna Journal of Science and Agriculture, 5: 140-150.

[4] Habauzit V, and Morand C. (2012). Evidence for a protective effect of polyphenols-containing foods on cardiovascular health: an update for clinicians. Therapeutic Advances in Chronic disease, 3:87-106.

[5] Pandey, K. B. and Rizvi, S. I. (2009). Plant polyphenols as dietary antioxidants in human health and disease. Oxidative Medicine and Cellular Longevity, 2:270-278.

[6] Johnson, I. T. (2013). Phytochemicals and health. In: Handbook of Plant Food Phytochemicals: source, stability and extraction. Ed: Tiwari, B. K., Brunton, N. P., Brennan, C. S. (2013). John Wiley \& Sons Ltd, West Sussex, UK, Pp. 49-67.

[7] Anal, A. K. (2013). Food processing by-products. In: Handbook of Plant Food Phytochemicals: source, stability and extraction. Ed: Tiwari, B. K., Brunton, N. P., Brennan, C. S. (2013). John Wiley \& Sons Ltd, West Sussex, UK, Pp. 180-192.

[8] Tiwari, U. and Cummins, E. (2013). Fruits and vegetables. In: Handbook of Plant Food Phytochemicals: source, stability and 
extraction. Ed: Tiwari, B. K., Brunton, N. P., Brennan, C. S. (2013). John Wiley \& Sons Ltd, West Sussex, UK, Pp. 107-129.

[9] Ajila, C.M., Bhat, S. G and Rao, U. J. S. P. (2007). Valuable components of raw and ripe peels from two Indian mango varieties. Food Chem., 102: S1006-1011.

[10] Kim, Y., Brecht, J. K. and Talcott, S. T. (2007). Antioxidant phytochemical and fruit quality changes in mangoes (Mangifera indica L.) following hot water immersion and controlled atmosphere storage. Food Chemistry, 105, 1327-1334.

[11] Ajila, C. M., Aalami, A., Leelavathi, K., and Rao, U. J. S. P. (2010). Mango peel powder: a potential source of antioxidant and dietary fiber in marcaroni preparations. Innovative Food Science and Emerging Technologies, 11, 219-224.

[12] Onuh, J. O., Girgih, A. T., Aluko, R. E., \& Aliani, M. (2014). In vitro antioxidant properties of chicken skin enzymatic protein hydrolysates and membrane fractions. Food Chemistry, 150, 366-373.

[13] Martinez-Maqueda, D., Miralles, B., Recio, I., and HernandezLedesma, B. (2012). Antihypertensive peptides from food proteins: a review. Food and Function, 3, 350-361.

[14] Ryan, J. T., Ross, R. P., Bolton, D., Fitzgerald, G. F., \& Stanton, C. (2011). Bioactive peptides from muscle sources: meat and fish. Nutrients, 3, 765-791.

[15] Kim, Y., Lounds-Singleton, A. J., Talcott, S. T. (2009). Antioxidant phytochemical and quality changes associated with hot water immersion treatment of mangoes (Mangifera indica L.) Food Chemistry, 115, 989-993.

[16] Palafox-Carlos, H., Yahia, E., Islas-Osuna, M. A., GutierrezMartinez, P., Robles-Sanchez, M., Gonzalez-Aguilar, A. (2012). Effect of ripeness stage of mango fruits (Mangifera indica L., cv Ataulfo) on physiological parameters and antioxidant activity. Scientia Horticulturae, 135, 7-13.

[17] Badifu, G. I. O., Illochi, J. C., Dutse, J. V. and Akpapunam, M. A. (2000). Use of mango mesocarp flour to enrich the provitamin A content of a nutritional complementary food blend of maize and soybean flour for porridge. Food. Bull, Vol. 2, 21-26.

[18] AOAC (2010). Official Methods of Analysis. Association of Association Official Analytical Chemists, Washington DC.

[19] AACC (2000). Approved Methods of the American Association of
Cereal Chemists. American Association of Cereal Chemists, Inc; St. Paul, Minnesota, USA.

[20] Ihekoronye, A. I and Ngoddy, P. O. (1985). Integrated Food Science and Technology for the Tropics. Macmillan press publisher London. pp. 10-26, 293-300.

[21] Reddy, N. N. and Sistrunk, W. A. (1980). Effects of cultivar, size, storage and cooking methods on carbohydrates and some nutrients of sweet potatoes. J. Food Sci., 45 (3), 682-684.

[22] Pearson, O. (1991).Composition and Analysis of foods. $9^{\text {th }}$ edition (ED) Kirk, R. S. and Sawyer, R. Longman Scientific and Technical, Essex, England, Pp. 8-42, 299-300.

[23] Harbone, J. B. (1976). Phytochemicals methods a guide to modern technique of plant analysis. p. 1-150. London: Chapman and Hall

[24] Woisky, R. G. and Salatino, A. (1998). Analysis of propolis: some parameters and procedures for chemical quality control. J. Apicultural research, 37 (2), 95-105.

[25] Burns, J., Fraser, P. D. and Bramley, P. M. (2003). Identification and quantification of carotenoids tocopherols and chlorophyll in commonly consumed fruits and vegetables. Phytochemistry, 62, 939-947.

[26] Grussu, D., Stewart, D., McDougall, G. J. (2011). Berry polyphenols inhibit $\alpha$-amylase in vitro: Identifying active components in rowanberry and raspberry. Journal of Agricultural and Food Chemistry, 59:2324-2331.

[27] Brand-Williams, W., Cuvelier, M., Berset, C. (1995). Use of a free radical method to evaluate antioxidant activity. LWT-Food Sci. Technology, 28, 25-30.

[28] Ashoush, I. S and Gadallah, M. G. E. (2011). Utilization of mango peels and kernels powders as sources of phytochemicals in biscuits. World Journal of Dairy \& Food Sciences, 6 (1): 35-42.

[29] Ayala-Zavala, J. F., Rosas-Dominguez, C. Vega-Vega, V. and Gonzalez-Aguilar, G. A. (2010). Antioxidant enrichment and antimicrobial arotection of fresh-cut fruits using their own byproducts: looking for integraleExploitation. J. Food Sci., 75(8): R175-R181.

[30] Ribeiro, S., Barbosa, L., Queiroz, J., Knodler, M. and Shieber, A (2008). Phenolic compounds and antioxidant capacity of Brazilian mango (Mangifera indica L.) varieties. Food Chemistry, 110, 620627. 